\title{
Pengaruh Frekuensi dan Periode Pemberian Pakan yang Berbeda terhadap Tingkah Laku Makan Burung Puyuh Petelur
}

\author{
The Effect of Different Frequency and Periods of Feeding on Behavior of Quail Laying Birds
}

\author{
H. R. Tamba, E. Suprijatna dan U. Atmomarsono
}

\author{
Program Studi S1-Peternakan \\ Fakultas Peternakan dan Pertanian, Universitas Diponegoro, Semarang \\ Corresponding e-mail: hendrareynaldi@yahoo.com
}

\begin{abstract}
Research aims to evaluate the influence of the frequency and period of the different feed to conduct quail laying on environmental conditions temperaturnya fluctuate tropical.The research uses 180 tail quail female age 21 days randomly placed in a cage battery. Any unit experiment consisting of 5 tail.The research uses commercial feed b11 in the period grower and b82 p in the period layer.The treatment was conducted over 9 sunday that begins at the age of 5 sunday reached the age of 13 weeks. The research uses random design complete ( ral ) pattern factorials with 2 factors, the frequency of (A) and A1 (1 time), A2 (2 times) and A3 (3 times) and period (B) to B1 (5:00 to 21:00 pm), B2 (07:00 to 21:00 GMT) and B3 (09:00 to 21:00 GMT). The parameters observed were the behavior of feeding, drinking, walking and resting. The data were analyzed for variance with $\mathrm{F}$ test at $5 \%$ level and continued Duncan Double Area Test. The results showed that frequency and feeding period did not show significant interaction with eating behavior, drinking walking and rest, but feeding frequency was 1 times significantly $(\mathrm{P}<0,05)$ to feeding behavior at the beginning of production. It was concluded that when viewed from the eating behavior, the combination of frequency treatment 1 times with a period of administration of 14 hours (A1B2) showed more quail feeding activity.
\end{abstract}

Key words: feeding frequency, period of feeding, behavior, quail laying.

\begin{abstract}
ABSTRAK
Penelitian bertujuan untuk mengevaluasi pengaruh frekuensi dan periode pemberian pakan yang berbeda untuk melakukan peletakan puyuh pada kondisi lingkungan suhunya berfluktuasi tropis. Penelitian ini menggunakan puyuh ekor 180 ekor betina usia 21 hari yang ditempatkan secara acak di dalam kandang baterai. Setiap unit percobaan terdiri dari 5 ekor .Penelitian menggunakan pakan komersial b11 pada periode grower dan b82 p pada periode layer. Perlakuan dilakukan lebih dari 9 minggu yang dimulai pada usia 5 minggu mencapai usia 13 minggu. Penelitian ini menggunakan rancangan acak lengkap (ral) pola faktorial dengan 2 faktor, frekuensi (A) dan A1 (1 kali), A2 (2 kali) dan A3 (3 kali) dan periode (B) ke B1 (5:00 hingga 21:00 sore), B2 ( 07:00 hingga 21:00 GMT) dan B3 (09:00 hingga 21:00 GMT). Parameter yang diamati adalah perilaku makan, minum, berjalan dan istirahat. Data dianalisis varians dengan uji $\mathrm{F}$ pada level $5 \%$ dan dilanjutkan Uji Area Ganda Duncan. Hasil penelitian menunjukkan bahwa frekuensi dan periode menyusui tidak menunjukkan interaksi yang signifikan dengan perilaku makan, minum berjalan dan istirahat, tetapi frekuensi makan 1 kali signifikan ( $\mathrm{P}$ $<0,05)$ terhadap perilaku makan pada awal produksi. Disimpulkan bahwa bila dilihat dari perilaku makan, kombinasi perlakuan frekuensi 1 kali dengan periode pemberian 14 jam (A1B2) menunjukkan aktivitas makan puyuh yang lebih banyak.
\end{abstract}

Kata kunci: frekuensi makan, lama menyusui, perilaku, peletakan puyuh.

\section{PENDAHULUAN}

Burung puyuh merupakan ternak lokal yang berpotensi sebagai sumber protein hewani bagi masyarakat. Peternakan burung puyuh di Indonesia saat ini mengalami perkembangan yang positif. Pemeliharaan burung puyuh petelur yang tergolong mudah serta menguntungkan karena awal produksi cepat, produktivitas tinggi, modal tidak terlalu besar dan tempat pemeliharaanya dapat diusahakan pada lahan yang terbatas.

Indonesia merupakan negara tropis memiliki iklim yang panas dan lembab akan tetapi akan berfluktuasi sepanjang hari. Temperatur lingkungan yang tinggi menyebabkan cekaman panas sehingga unggas akan cenderung menurunkan konsumsi pakan, meningkatkan konsumsi air minum dan banyak istirahat sebagai upaya 
adaptasi. Fluktuasi temperatur di Indonesia tertinggi yaitu $32,2{ }^{0} \mathrm{C}$ pada pukul 12:0013:00 dan terendah yaitu $19,0{ }^{\circ} \mathrm{C}$ pada pukul 05:00-06:00 (Hafidi et al., 2015). Ternak unggas yang menderita stress akan terlihat banyak mengonsumsi air minum, nafsu makan turun, gelisah dan mengepakngepakan sayap dilantai kandang (Tamzil, 2014). Unggas memiliki mekanisme dalam menjaga suhu tubuh agar tetap stabil yaitu melalui mekanisme radiasi, konduksi dan konveksi. Unggas banyak menggunakan energi untuk melepaskan panas untuk menstabilkan suhu tubuh saat terjadi heat stress (Komalasari, 2014). Pengalihan energi untuk menstabilkan suhu tubuh akan mengakibatkan unggas untuk mengurangi aktivitas gerak dan lebih banyak istirahat.

Xie et al. (2017) melaporkan bahwa unggas akan cenderung menurunkan konsumsi pakan saat kondisi heat stress dan akan banyak melakukan aktivitas makan saat kondisi lingkungan nyaman. Frekuensi pemberian pakan harus disesuaikan dengan temperatur, dimana kebutuhan energi meningkat dan unggas sangat responsif terhadap temperatur yang nyaman untuk melakukan aktivitas makan. Penelitian Morissey et al. (2014) menyatakan bahwa unggas dengan frekuensi pemberian sering dengan pakan dibatasi menunjukkan tingkah laku istirahat dan berjalan yang tinggi karena unggas masih dalam keadaan lapar. Penelitian Svihus et al. (2001) menyatakan bahwa meskipun unggas diberi pakan frekuensi 5 kali dengan rentang tersedia pakan 6 jam dibandingkan dengan tersedia pakan 18 jam, unggas tetap mampu untuk beradaptasi dengan cepat.

Unggas akan menunjukkan tingkah laku sesuai kondisi lingkungan guna memenuhi kebutuhan pakan, oleh karena itu manajemen pemberian pakan harus di sesuaikan dengan kondisi lingkungan dan pola tingkah laku unggas. Pakan harus disediakan pada waktu ayam butuh makan atau saat temperatur lingkungan nyaman, sehingga unggas akan aktif melakukan aktivitas makan. Penelitian Lambey et al. (2015) menjelaskan bahwa aktivitas makan unggas paling banyak dilakukan pada pagi, siang, dan sore hari, sedangkan penelitian Hebatallah et al. (2016) menjelaskan bahwa ada pergeseran pola tingkah laku dimana menjadi maksimum pada pagi, sore dan malam hari. Penelitian Khalil et al. (2012) menyatakan bahwa pada saat suhu $35^{\circ} \mathrm{C}$ burung puyuh akan lebih banyak melakukan aktivitas istirahat daripada berjalan sedangkan pada suhu $25^{\circ} \mathrm{C}$ puyuh akan banyak melakukan aktivitas makan. Penelitian Diarra dan Tabuaciri (2014) menyatakan bahwa pemberian pakan hanya pada saat kondisi lingkungan nyaman akan meningkatkan tingkah laku makan dan akan mengkompensasi nutrient yang hilang selama periode tidak diberi pakan. Oleh karena itu perlu dilakukan penelitian mengamati pengaruh frekuensi dan periode pemberian pakan terhadap tingkah laku makan, minum, istirahat dan berjalan yang optimal, sebagai pertimbangan didalam mengambil kebijakan manajemen pemberian pakan.

\section{MATERI DAN METODE}

Materi yang digunakan dalam penelitian adalah puyuh betina sebanyak 180 ekor umur 3 minggu dengan bobot badan \pm 130 g. Penelitian menggunakan pakan komersial B11 untuk periode grower dan B82 P untuk periode layer dengan kandungan nutrisi pada Tabel 1. Ransum pada periode grower minimal kandungan protein kasar $20 \%$ dan energi metabolis 2700 $\mathrm{kkal} / \mathrm{kg}$ dan periode layer energi metabolis $2900 \mathrm{kkal} / \mathrm{kg}$ protein kasar 22\%. Kandang yang digunakan adalah kandang battery bertingkat 4 , masing-masing 9 kotak terbuat

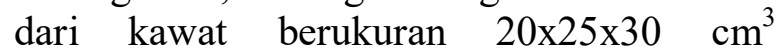
berjumlah 36 petak. Setiap petak kandang diisi \pm 5 ekor burung puyuh. Pemeliharaan dilakukan selama 11 minggu. Puyuh dipelihara pada kandang dari umur 3 minggu atau fase grower. Puyuh ditempatkan pada kandang sesuai dengan perlakuannya dimana sebelumnya telah dilakukan pengacakan. 
Tabel 1. Kandungan nutrisi pakan puyuh petelur

\begin{tabular}{|c|c|c|c|c|c|c|}
\hline Jenis Pakan & Air & $\mathrm{Abu}$ & PK & LK & SK & EM \\
\hline & ------ & - & -----. & 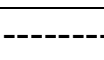 & - & $\mathrm{Kkal} / \mathrm{kg}$ \\
\hline B11 & 12,51 & 5,31 & 21,06 & 3,74 & 7,07 & 2934,77 \\
\hline B82 P & 11,62 & 11,21 & 19,76 & 3,34 & 7,41 & 2727,06 \\
\hline
\end{tabular}

Keterangan : Dianalisis Proksimat di Laboratorium Ilmu Nutrisi dan Pakan, Fakultas Peternakan dan Pertanian, Universitas Diponegoro, Semarang (2016). Perhitungan berdasarkan rumus Balton EM $(\mathrm{kkal} / \mathrm{kg})=$ $40,81\{0,87(\mathrm{PK}+2,25 \times \mathrm{LK}+\mathrm{BETN})+\mathrm{k}\}$

Pakan diberikan dijatah sesuai dengan kebutuhan harian setiap minggunya dan air minum secara ad libitum selama penelitian. Pencahayaan kandang dengan sinar matahari dan menggunkan lampu pada malam hari untuk membantu penglihatan puyuh saat mengakses pakan. Perlakuan yang diberikan selama penelitian adalah 2 faktor, yaitu frekuensi (A) dengan A1 (1 kali), A2 (2 kali) dan A3 (3 kali) dan periode (B) dengan B1 (05.00-21.00 WIB), B2 (07.00-21.00 WIB) dan B3 (09.00-21.00 WIB).

Pengamatan dilakukan sesuai dengan perlakuan lamanya periode pemberian pakan. Teknik pengamatan yaitu dengan menentukan sampling 2 ekor puyuh dari masing-masing unit percobaan yang telah diberi tanda dengan pewarna makanan hijau dan merah. Pengambilan data dilakukan sebanyak 2 kali, pada saat awal produksi dan puncak produksi maing-masing selama satu hari, setiap 5 menit dilakukan pencatatan selama periode pemberian pakan.

Cara pengamatan :

1. Perilaku makan, diukur dengan mencatat puyuh ketika melakukan aktifitas mematuk pakan di tempat pakan.

2. Perilaku minum, diukur dengan mencatat puyuh ketika melakukan aktifitas menghisap air dari tempat minum.

3. Perilaku istirahat, diukur dengan mencatat puyuh ketika melakukan aktifitas rebah atau posisi mengeram dengan dada menempel pada litter dengan mata terbuka atau berkedip.

4. Perilaku berjalan, diukur dengan mencatat puyuh ketika melakukan aktifitas lokomosi (berpindah tempat) dalam kelompok tersebut.
Penelitian menggunakan rancangan acak lengkap (RAL) pola faktorial 3 x 3 dan 4 ulangan. Data yang diperoleh dianalisis ragam dengan uji $\mathrm{F}$ pada taraf signifikasi 5\% dan jika ada pengaruh perlakuan dilanjutkan Uji Wilayah Ganda Duncan untuk mengetahui perbedaan antar perlakuan.

\section{HASIL DAN PEMBAHASAN}

Selama penelitian dilakukan pengukuran terhadap suhu dan kelembaban, kemudian dilakukan penghitungan HSI (heat stress index) sebagai indikator unggas sudah terpapar cekaman heat stress, data disajikan pada Tabel 2 dan Tabel 3. Kondisi lingkungan dalam maupun luar kandang menunjukkan bahwa suhu ( $\left.>27^{\circ} \mathrm{C}\right)$, kelembaban ( $>70 \%)$ maupun nilai HSI diatas ambang batas 94 (heat stress index) sepanjang pagi, siang maupun malam hari berada pada zona diluar kondisi nyaman burung puyuh atau sudah mengalami heat stress. Keadaan heat stress yang dialami oleh burung puyuh berbeda-beda, pada pagi hari suhu rendah $\left(<27^{\circ} \mathrm{C}\right)$ sedangkan kelembaban tinggi ( $>70 \%$ ), pada siang hari suhu tinggi $\left(>27^{\circ} \mathrm{C}\right)$ sedangkan kelembaban rendah $(<$ $70 \%)$ dan malam hari suhu rendah $\left(<27^{\circ} \mathrm{C}\right)$ sedangkan kelembaban tinggi ( $>70 \%)$ seperti terlihat pada Ilustrasi 1. dan Ilustrasi 2. Menurut Ocak dan Erener (2005) bahwa suhu thermoneutral zone burung puyuh berada pada suhu $24{ }^{\circ} \mathrm{C}$ dan kelembaban kisaran 60 - 70\%. Khalil et al. (2012) menyatakan bahwa efek negatif dari heat stress pada unggas akan mempengaruhi efisiensi pakan, pertambahan bobot badan harian, persentase karkas dan daya tahan tubuh. Ditambahkan Vercese et al. (2012) bahwa heat stress terjadi pada kondisi suhu 
dan kelembaban lingkungan yang melebihi konsumsi pakan juga akan berkurang. angka heat stress indeks yang optimal dan

Tabel 2. Suhu, kelembaban dan Heat stress Index (HSI) di dalam kandang

\begin{tabular}{cccc}
\hline Waktu & Suhu $\left({ }^{\circ} \mathrm{C}\right)$ & RH $(\%)$ & HSI \\
\hline 05.00 & 26,06 & 86,39 & 112,45 \\
06.00 & 26,30 & 86,61 & 112,91 \\
07.00 & 27,69 & 83,92 & 111,61 \\
09.00 & 30,00 & 76,75 & 106,75 \\
rerata & 27,51 & 83,42 & 110,93 \\
12.00 & 31,35 & 72,05 & 103,40 \\
rerata & 31,35 & 72,05 & 103,40 \\
17.00 & 28,25 & 79,42 & 107,67 \\
18.00 & 28,16 & 81,02 & 109,18 \\
20.00 & 27,24 & 83,02 & 110,26 \\
rerata & 27,89 & 81,15 & 109,04 \\
\hline
\end{tabular}

Keterangan : Nilai batas normal heat stress index pada puyuh $\leq 94$

Tabel 3. Suhu, kelembaban dan Heat stress Index (HSI) di luar kandang

\begin{tabular}{cccc}
\hline Waktu & Suhu $\left({ }^{\circ} \mathrm{C}\right)$ & RH $(\%)$ & HSI \\
\hline 05.00 & 24,50 & 90,24 & 114,74 \\
06.00 & 24,85 & 89,69 & 114,54 \\
07.00 & 26,10 & 86,25 & 112,35 \\
09.00 & 28,48 & 77,59 & 106,07 \\
rerata & 25,98 & 85,94 & 111,92 \\
12.00 & 30,10 & 72,39 & 102,49 \\
rerata & 30,10 & 72,39 & 102,49 \\
17.00 & 27,41 & 81,31 & 108,72 \\
18.00 & 27,10 & 83,05 & 110,15 \\
20.00 & 25,66 & 87,53 & 113,19 \\
rerata & 26,72 & 83,96 & 110,68 \\
\hline
\end{tabular}

Keterangan : Nilai batas normal heat stress index pada puyuh $\leq 94$

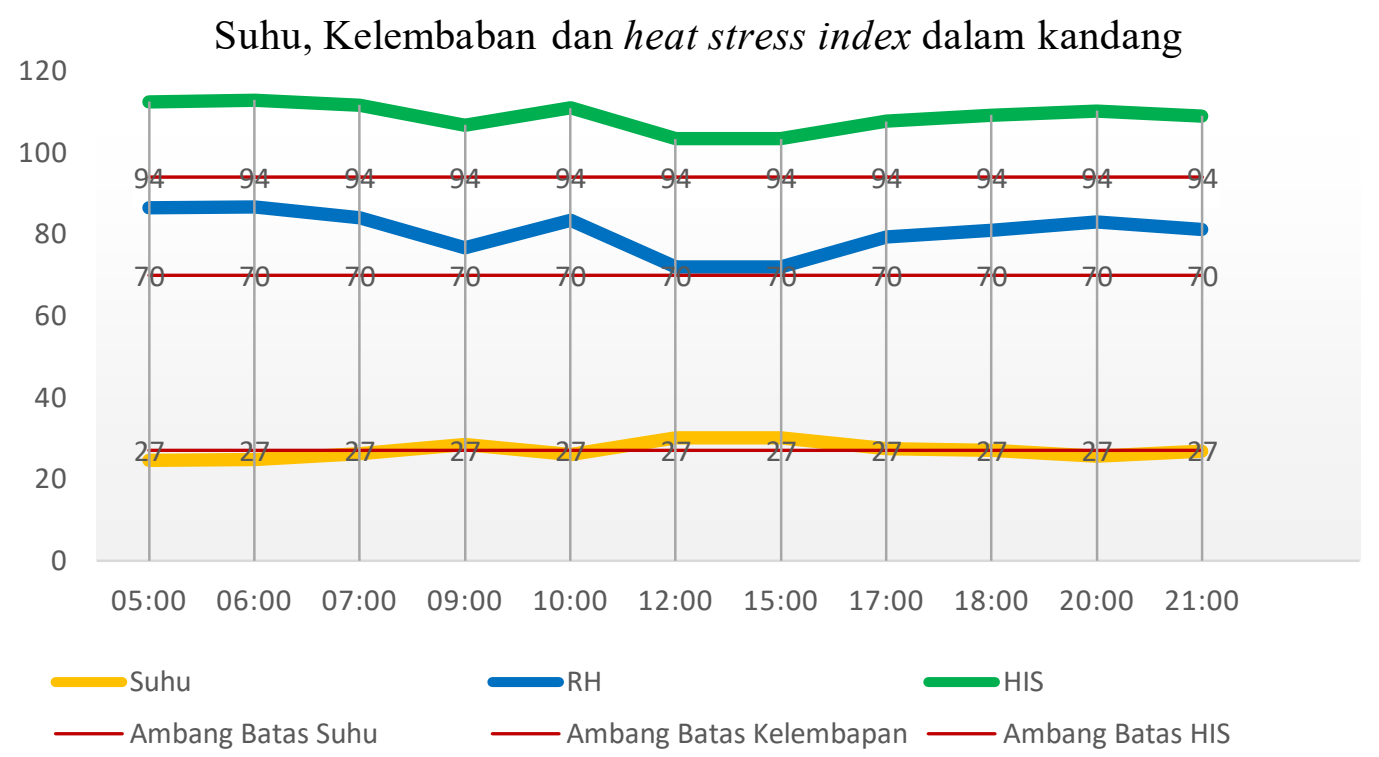

Ilustrasi 1. Grafik Suhu, kelembaban dan heat stress index dalam kandang 


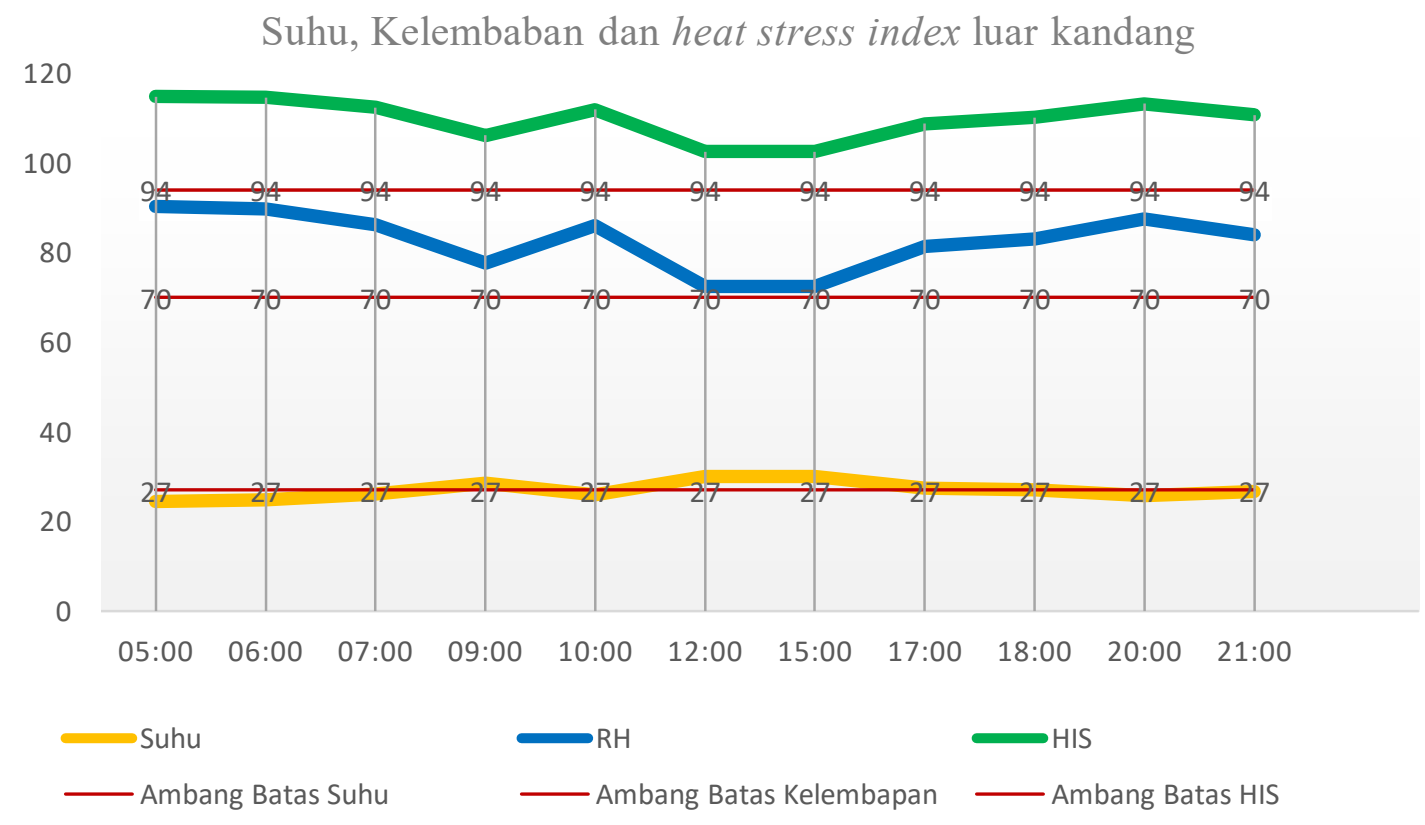

Ilustrasi 2. Grafik Suhu, kelembaban dan heat stress index luar kandang

\section{Tingkah Laku Makan}

Data hasil penelitian pengaruh frekuensi dan periode pemberian pakan terhadap tingkah laku makan burung puyuh petelur dilihat pada Tabel 4.

Tabel 4. Rata-rata tingkah laku makan burung puyuh petelur dengan frekuensi dan periode pemberian pakan yang berbeda

\begin{tabular}{cccccc}
\hline $\begin{array}{c}\text { Masa } \\
\text { Produksi }\end{array}$ & \multirow{2}{*}{ Frekuensi } & \multicolumn{3}{c}{ Periode Pemberian } & \multirow{2}{*}{ Rata-rata } \\
\hline \multirow{3}{*}{ Awal Produksi } & & $-------------k a l i /$ ekor/hari-------------- & \\
(Umur 8 minggu) & A1 & 22,88 & 24,88 & 22,00 & $23,25^{\mathrm{a}}$ \\
& A2 & 13,50 & 22,50 & 14,25 & $16,75^{\mathrm{b}}$ \\
& A3 & 19,13 & 9,63 & 11,00 & $13,31^{\mathrm{b}}$ \\
\hline Puncak Produksi & A1 & 22,88 & 24,88 & 18,50 & 22,09 \\
(Umur 13 minggu & A2 & 13,50 & 22,50 & 14,25 & 16,75 \\
& A3 & 24,25 & 14,13 & 14,13 & 17,50 \\
\hline
\end{tabular}

Keterangan : Superskrip dengan huruf yang berbeda pada kolom yang sama menunjukkan perbedaan yang nyata $(\mathrm{P}<0,05)$.

Frekuensi dan periode pemberian pakan tidak menunjukkan interaksi yang nyata terhadap tingkah laku makan hal ini disebabkan pada saat pemberian pakan suhu maupun kelembaban sudah berada pada zona yang tidak nyaman bagi unggas. Frekuensi pemberian pakan memberikan pengaruh nyata $(p<0,05)$ terhadap tingkah laku makan pada awal produksi akan tetapi periode tidak berpengaruh nyata. Hal ini disebabkan oleh burung puyuh masih dalam proses adaptasi, suhu lingkungan pada saat puncak produksi juga menunjukkan kondisi lingkungan yang lebih nyaman dan pada saat awal produksi unggas akan lebih banyak mengonsumsi pakan untuk pembentukan telur, akan tetapi saat puncak produksi unggas telah mampu beradaptasi dengan lingkungan. Berdasarkan uji lanjut duncan menunjukkan bahwa frekuensi pemberian pakan 1 kali diperoleh hasil tingkah laku makan yang lebih tinggi, karena pakan telah disajikan sekaligus dan burung puyuh mampu mengatur konsumsi pakan sesuai dengan kebutuhannya saat kondisi lingkungan yang nyaman. Hal ini sesuai dengan pendapat Mills et al. (1997) 
yang berpendapat bahwa tingkah laku makan burung puyuh didasarkan pada frekuensi pemberian pakan, semakin jarang diberi pakan maka burung puyuh akan lebih cepat menghabiskan pakannya untuk memenuhi kapasitas saluran pencernaannya. Penurunan tingkah laku makan diperoleh pada frekuensi pemberian pakan dua kali dan tiga kali, hal ini disebabkan oleh pemberian pakan yang dijatah, sehingga saat pakan diberikan, burung puyuh akan meningkatkan konsumsi makan karena burung puyuh masih dalam keadaan lapar. Sesuai dengan pernyataan Hardini (2011) tingkah laku makan akan muncul saat unggas merasa lapar. Tingkah laku makan dan minum digunakan sebagai sumber energi, untuk melakukan aktifitas lainnya.

Periode pemberian pakan tidak memberikan pengaruh nyata $(p>0,05)$ terhadap tingkah laku makan. Hal ini disebabkan oleh ketersediaan pakan selama 12, 14 dan 16 jam telah mampu memberikan kesempatan untuk burung puyuh dalam mengonsumsi pakan sesuai kebutuhannya. Muharlien et al., (2010) menyatakan bahwa konsumsi pakan unggas akan lebih baik jika diberikan secara ad-libitum dibandingkan pemberian pakan dijatah. Diarra dan Tabuaciri (2014) menyatakan bahwa faktor yang mempengaruhi tingkah laku makan burung puyuh adalah ketersediaan pakan, umur dan suhu lingkungan yang nyaman.

\section{Tingkah Laku Minum}

Data hasil penelitian pengaruh frekuensi dan periode pemberian pakan terhadap tingkah laku minum burung puyuh petelur dilihat pada Tabel 5 .

Hasil penelitian menunjukkan bahwa frekuensi dan periode pemberian pakan tidak menunjukkan interaksi yang nyata terhadap tingkah laku minum hal ini disebabkan oleh pemberian air minum yang diberikan secara ad libitum, sehingga unggas mampu menyesuaikan tingkah laku minum kapan saja saat kondisi heat stress. Faktor frekuensi maupun faktor periode pemberian pakan tidak memberikan pengaruh nyata $(p>0,05)$ terhadap tingkah laku minum pada awal produksi maupun pada periode puncak produksi. Tingkah laku minum dipengaruhi oleh konsumsi ransum, semakin sering pemberian pakan diharapkan akan berdampak pada peningkatan konsumsi air minum pada burung puyuh. Glatz (2011) menjelaskan bahwa tingkah laku minum akan berkorelasi dengan konsumsi pakan dan dengan demikian setiap penurunan konsumsi air karena tidak tersedianya air di dalam tempat minum maupun pengaruh lingkungan akan mengakibatkan penurunan konsumsi pakan pada tingkat yang berbeda-beda, tergantung pada usia unggas. Burung puyuh mengkonsumsi air minum untuk melancarkan proses pencernaan dan membuang panas dalam tubuh sehingga dapat menurunkan suhu tubuh apabila suhu lingkungan sedang meningkat.

Tabel 5. Rata-rata tingkah laku minum burung puyuh petelur dengan frekuensi dan periode pemberian pakan yang berbeda

\begin{tabular}{ccccc}
\hline \multirow{2}{*}{ Masa Produksi } & \multirow{2}{*}{ Frekuensi } & \multicolumn{3}{c}{ Periode Pemberian } \\
& & B1 & B2 & B3 \\
\hline \multirow{2}{*}{ Awal Produksi } & A1 & 8.38 & 6.50 & 5.00 \\
(Umur 8 minggu) & A2 & 6.25 & 5.50 & 6.75 \\
& A3 & 4.75 & 4.00 & 5.50 \\
\hline Puncak Produksi & A1 & 8.38 & 6.50 & 5.00 \\
(Umur 13 minggu & A2 & 6.25 & 5.50 & 6.75 \\
& A3 & 6.88 & 7.00 & 6.00 \\
\hline
\end{tabular}

Keterangan : Rata-rata tingkah laku minum burung puyuh petelur menunjukkan tidak ada perbedaan yang nyata $(\mathrm{P}>0,05)$ 
Nuriyasa (2003) menyatakan bahwa tingkah laku minum merupakan suatu upaya adaptasi menjaga keseimbangan air dalam tubuh pada saat suhu lingkungan yang tinggi dan membantu dalam proses pencernaan pakan. Li et al. (2015) juga menyatakan bahwa heat stress atau keadaan pada saat suhu lingkungan meningkat, maka konsumsi air minum juga akan semakin meningkat.

\section{Tingkah Laku Istirahat}

Data hasil penelitian pengaruh frekuensi dan periode pemberian pakan terhadap tingkah laku istirahat burung puyuh petelur dilihat pada Tabel 6 .

Hasil penelitian menunjukkan bahwa frekuensi dan periode pemberian pakan tidak menunjukkan interaksi yang nyata terhadap tingkah laku istirahat hal ini disebabkan oleh burung puyuh telah mengalami kondisi heat stress pada pagi maupun sore hari. Faktor frekuensi pemberian pakan yang berbeda tidak memberikan pengaruh nyata $(p>0,05)$ terhadap tingkah laku istirahat pada awal produksi maupun pada periode puncak produksi. Hal ini disebabkan oleh unggas telah mengalami heat stress pada pagi hari karena kondisi kelembaban yang tinggi sedangkan suhu rendah, pada siang hari kelembaban rendah dan suhu yang tingggi. Hal ini sesuai dengan pendapat Khalil et al. (2012) yang menyatakan bahwa pada saat kondisi puyuh sudah kenyang dan belum tersedianya pakan lagi, maka aktivitas istirahat dan duduk akan semakin banyak. Periode pemberian pakan yang berbeda tidak memberikan pengaruh nyata $(p>0,05)$ terhadap tingkah laku istirahat pada awal produksi maupun pada periode puncak produksi. Hal ini disebabkan oleh kondisi lingkungan yang berfluktuatif pada pagi dan siang hari sehingga tingkah laku istirahat akan lebih banyak pada saat kondisi nyaman pada malam hari. Cornetto dan Esteves (2001) menyatakan bahwa pada keadan lingkungan yang nyaman, unggas lebih banyak melakukan istirahat karena merasa aman dari pengaruh lingkungan yaitu pada malam hari. Burung puyuh merupakan hewan diurnal sehingga, akan banyak melakukan aktivitas pada pagi dan siang hari, sedangkan saat malam hari akan lebih banyak beristirahat.

Tabel 6. Rata-rata tingkah laku istirahat burung puyuh petelur dengan frekuensi dan awal pemberian pakan yang berbeda

\begin{tabular}{ccccc}
\hline \multirow{2}{*}{ Masa Produksi } & \multirow{2}{*}{ Frekuensi } & \multicolumn{3}{c}{ Periode Pemberian } \\
& & B1 & B2 & B3 \\
\hline \multirow{2}{*}{ Awal Produksi } & A1 & 77.50 & 76.00 & 64.50 \\
(Umur 8 minggu) & A2 & 80.25 & 69.63 & 69.25 \\
& A3 & 54.63 & 69.25 & 69.75 \\
\hline Puncak Produksi & A1 & 77.50 & 76.00 & 64.50 \\
(Umur 13 minggu & A2 & 80.25 & 69.63 & 69.25 \\
& A3 & 59.00 & 73.75 & 74.63 \\
\hline
\end{tabular}

Keterangan : Rata-rata tingkah laku istirahat burung puyuh petelur menunjukkan tidak ada perbedaan yang nyata $(\mathrm{P}>0,05)$ 


\section{Tingkah Laku Berjalan}

Data hasil penelitian pengaruh frekuensi dan periode pemberian pakan terhadap tingkah laku berjalan burung puyuh petelur dilihat pada Tabel 7.

Tabel 7. Rata-rata tingkah laku berjalan burung puyuh petelur dengan frekuensi dan awal pemberian pakan yang berbeda

\begin{tabular}{|c|c|c|c|c|}
\hline \multirow{2}{*}{ Masa Produksi } & \multirow{2}{*}{ Frekuensi } & \multicolumn{3}{|c|}{ Periode Pemberian } \\
\hline & & $B 1$ & B2 & B3 \\
\hline \multirow{4}{*}{$\begin{array}{c}\text { Awal Produksi } \\
\text { (Umur } 8 \text { minggu) }\end{array}$} & & \multicolumn{3}{|c|}{----------------kali/ekor/hari--------------- } \\
\hline & A1 & 86.50 & 69.13 & 58.38 \\
\hline & A2 & 98.00 & 77.88 & 61.00 \\
\hline & A3 & 86.50 & 64.88 & 42.75 \\
\hline Rata - rata & & $90.33^{\mathrm{a}}$ & $70.63^{b}$ & $54.04^{\mathrm{b}}$ \\
\hline \multirow{3}{*}{$\begin{array}{l}\text { Puncak Produksi } \\
\text { (Umur } 13 \text { minggu }\end{array}$} & A1 & 86.50 & 69.13 & 58.38 \\
\hline & $\mathrm{A} 2$ & 98.00 & 77.88 & 61.00 \\
\hline & A3 & 109.88 & 75.38 & 55.25 \\
\hline Rata - rata & & $98.13^{\mathrm{a}}$ & $74.13^{\mathrm{b}}$ & $58.21^{b}$ \\
\hline
\end{tabular}

Keterangan : Superskrip dengan huruf yang berbeda pada baris yang sama menunjukkan perbedaan yang nyata $(\mathrm{P}<0,01)$.

Hasil penelitian menunjukkan bahwa frekuensi dan periode pemberian pakan tidak menunjukkan interaksi yang nyata terhadap tingkah laku berjalan hal ini disebabkan oleh pengaruh kondisi lingkungan yang berfluktuatif dan unggas mengalami heat stress sehingga unggas akan mengurangi tingkah laku berjalan guna mengurangi produksi panas tubuh. Faktor frekuensi pemberian pakan yang berbeda tidak memberikan pengaruh nyata $(p>0,05)$ terhadap tingkah laku berjalan pada awal produksi maupun pada periode puncak produksi. Hal ini disebabkan karena burung puyuh akan melakukan aktivitas berjalan untuk mengakses pakan maupun air minum saat kondisi nyaman sedangkan kondisi lingkungan berada diluar zona nyaman dan burung puyuh mengalami heat stress pada pagi dan siang hari. Pritchard (1995) menjelaskan bahwa tingkah laku berjalan merupakan pergerakan ayam untuk melakukan aktivitas yang berpindah tempat saat ayam berada jauh dari tempat pakan maka ayam tersebut akan melakukan tingkah laku berjalan, yakni berpindah tempat dari satu tempat ke tempat lainnya untuk mendapatkan makan ataupun minum.

Faktor periode pemberian pakan 16 jam memberikan pengaruh sangat nyata $(p<0,01)$ terhadap tingkah laku berjalan pada awal produksi maupun pada periode puncak produksi. Hal ini disebabkan karena burung puyuh akan melakukan aktivitas berjalan untuk mengakses pakan pada saat kondisi nyaman, sehingga saat kondisi nyaman yang panjang melalui metode pemberian pakan 16 jam akan membuat burung puyuh lebih banyak melakukan aktivitas dan hal ini selaras dengan tingkah laku berjalan. Renden et al. (1996) tingkah laku berjalan yang dilakukan unggas adalah bagian dari ekspresi tingkah laku, yakni berpindah tempat dari satu tempat ke tempat lainnya, untuk mendapatkan makan ataupun minum khususnya saat kondisi nyaman melalui memperpanjang waktu mengakses pakan dengan menyalakan lampu pada malam hari.

\section{KESIMPULAN}

Berdasarkan penelitian ini dapat disimpulkan bahwa temperatur dan kelembaban lingkungan berfluktuasi sepanjang hari, dan nilai heat stress index berada diatas batas cekaman panas heat stress menunjukkan bahwa burung puyuh telah mengalami heat stress sepanjang hari. Perlakuan kombinasi frekuensi 1 kali dengan periode pemberian 14 jam (A1B2) menunjukkan aktivitas makan burung puyuh 
yang lebih banyak jika ditinjau dari tingkah laku makan.

\section{DAFTAR PUSTAKA}

Abioja. M. O., K. B Ogundimu and T. E Akibo. 2012. Growth, mineral deposition, and physiological responses of broiler chickens offered honeyin drinking water during hot-dry season. J. Zool. 10 (6): 1-6.

Butcher, G. D and Miles R. 2003. Heat stress management in broilers. Department of Agriculture, UF/IFAS Extension Service, University of Florida. 65 (1) : 1-2.

Cornetto, T. and I. Esteves. 2001. Behaviour of the domestic fowl in the presence of vertical panels. J. of Poult. Sci. 80 (2) : 1455-1465.

Diarra, S. S and P. Tabuaciri. 2014. Feeding management of poultry in high environmental temperatures. Int. J. of Poult. Sci. 13 (11): 657-661.

Glatz, P. C. 2001. Effect of cool drinking water on production and shell quality of laying hens in summer. Asian. Aust. J. Anim. Sci. 14 (6) : 850-854.

Hafidi, W., D. Pujiastuti., W. Harjupa. 2015. Analisis Variabilitas temperatur udara di daerah kototabang periode 20032012. J. Fisika Unand. 4 (2): 185-192.

Hebatallah, E., El-Shafaei., Mohamed, M., Sharaf dan R. R. Rashed. 2016. The Effect of Different Intervention Strategies to Alleviate Heat Stress on Behavior, Performance and some blood parameters of growing muscovy ducks. Alexandria J. of Vet. Sci. 48 (2): 69-76

Jahejo, A. R., N. Rajput., N. M. Rajput., I. H. Leghari., R. R. Kaleri., R. A. Mangi., M. K. Sheikh., and M. Z. Pirzado. 2016. Effects Of Heat Stress On The Performance Of Hubbard Broiler Chicken. Cells, Animal and Therapeutics. 2 (1) : 1-5
Khalil, H. A., M. Gerken, A.M. Hassanein and M. E. Mady. 2012. Behavioural responses of two Japanese quail lines differing in body weight to heat stress. Egyptian J. Anim. Prod. 47 : 151-158.

Komalasari, L. 2014. Dampak suhu tinggi terhadap respons fisiologi, profil darah dan performa produksi dua bangsa ayam berbeda. Sekolah Pascasarjana. Institut Pertanian Bogor, Bogor. (Tesis)

Lambey, L. J., R. R. Noor., W. Manalu dan D. Duryadi. 2011. Tingkah laku menetas piyik burung weris (gallirallus philipensis) dan burung dewasa dalam penangkaran. J. Veteriner .16 (2) : 274282.

Li, M., Wu. J dan Chen. Z. 2015. Effects of heat stress on the daily behavior of wenchang chickens. Brazilian J. of Poult. Sci. 17 (4) : 559-566.

Mills, A. D., L. L. Crawford., M. Domjam and J. M. Faure. 1997. The Behavior of the Japanese or domestic quail (Coturnix japonica). Neurosci. Biobehav. rev. 21 (3) : 261-281.

Morrissey, K. L. H., T. Widowski., S. Leeson V., Sandilands, A., Arnone and S. Torrey. 2014. The effect of dietary alterations during rearing on growth, productivity, and behavior in broiler breeder females. J. Poult Sci 93 (2) : 285-295.

Muharlien, Achmanu dan A. Kurniawan. 2010. Efek lama waktu pembatasan pemberian pakan terhadap performans ayam pedaging finisher. J. Ternak Tropika 11 (2) : 88-94.

Mujahid, A., I. Hagimori., K. Takahashi dan A. Matsuda. 2009. Nutritional Strategies to Enhance Efficiency and Production of Chickens under High Environmental Temperature. The $1^{\text {st }}$ International Seminar on Animal Industry : 2-12.

Nuriyasa, I. M. 2003. Pengaruh tingkat kepadatan ternak dan kecepatan angin 
dalam kandang terhadap indeks ketidaknyamanan dan penampilan ayam pedaging pada dataran rendah. Majalah Ilmiah Peternakan, Fakultas Peternakan Unud. 2 (6) : 40-45.

Prayuwidayati, M., T. Pasaribu., R. Palupi., K. G. Wiryawan., A. Sudarman., dan R. Mutia. 2012. The effects of dietary energy sources on immune organs of broilers exposed to heat stress. Proceeding of the 2nd International Seminar on Animal Industry. Hal : 276-27

Renden, J. A., E. T. Moran, Jr. and S. A. Kincaid. 1996. Lighting programs for broilers that reduce leg problems without loss of performance or yield. J. Poult. Sci. 7 (5) : 345-350.

Sulistyoningsih, M. 2004. Respon fisiologis dan tingkah laku ayam broiler periode starter akibat cekaman temperatur dan awal pemberian pakan yang berbeda. Program Studi Magister Ilmu Ternak. Fakultas Peternakan. Universitas Diponegoro, Semarang. (Tesis).

Svihus B. 2001. A consistent low starch digestibility observed in pelleted broiler chicken diets containing high levels of different wheat varieties. Anim. Feed Sci. Technol. Anim. Feed Sci. Technol. 92:45-49.

Tamzil, M. H. 2014. Stres panas pada unggas: metabolisme, akibat dan upaya penanggulangannya. Wartazoa 24 (2) : 57-66.

Xie, S., Erin J. T. and Todd J. M. W. 2017. Behavioural responses to heat in captive native Australian birds. J. E. Aus. Ornith. 117 (1) : 51-67. 